\title{
SLM-0J: Surrogate Learning Mechanism during Outbreak Juncture
}

\author{
Shahzad Ashraf ${ }^{* 1} \mid$ Zeeshan A. Arfeen ${ }^{2} \mid$ Muhammad A. Khan ${ }^{3}$ Tauqeer Ahmed ${ }^{1}$ \\ ${ }^{1}$ College of Internet of Things Engineering, Hohai University, Changzhou, Jiangsu, China \\ 2University College of Engineering \& Technology, The Islamia University of Bahawalpur, Pakistan \\ ${ }^{3}$ Department of Information and Communication Engineering,Dongguk University, Seoul, South Korea
}

To Cite this Article

Shahzad Ashraf, Zeeshan A. Arfeen, Muhammad A. Khan and Tauqeer Ahmed, "SLM-OJ: Surrogate Learning Mechanism during Outbreak Juncture", International Journal for Modern Trends in Science and Technology, Vol. 06, Issue 05, May 2020, pp.: 162-167; https://doi.org/10.46501/IJMTST060525

\section{Article Info}

Received on 02-April-2020, Revised on 28-April-2020, Accepted on 05-May-2020, Published on 22-May-2020.

\section{ABSTRACT}

During epidemic outbreak it is hard to continue formal leaning and training routines specially when whole world is facing corona virus fistula. It is crucial to identify and share the best practices and innovations to enable teaching and learning to take place during outbreak juncture. This will reinforce the basis for more sustainable and balanced schooling solutions as the crisis decreases. The biggest solution to cuts of schools is to plunge into cyberspace and distance learning, establishing a symbiosis between humans and the computers. Ideally, specific contents, learning outcomes, and a set of instructions are desirable. Use various media and technology, students can learn more in different ways and obtain varying results at various levels. Technologies can be compared along several characteristics. These features form a foundation for evaluating emerging innovations, seeing where they fit into the current environment and determining their potential benefits and limitations. Today, technology appears to become more communicative and richer in media, thereby giving educators and students powerful resources to achieve desired learning outcomes.

KEYWORDS: Learning system, formal education, technology, alternate, resources

Copyright (C) 2014-2020 International Journal for Modern Trends in Science and Technology

DOI: https://doi.org/10.46501/IJMTST060525

\section{INTRODUCTION}

Today whole world has been captured by a novel corona virus and necessary measures are being taken to tackle the spread of the virus such as lockdown, curfews, quarantines, travel restrictions, and school closures. Covid-19 outbreak has caused significant disruption to the provision of educational opportunities for more than 1.5 billion students and youth across the planet. We are facing another universal Volatile, Uncertain, Complex, and Ambiguous (VUCA) environment. What should be the role of policymakers, educational administrators, instructors, and learners in this unprecedented moment of crisis and emergency? After the end of the Cold War, the US Army coined the word "VUCA" and concentrated on developing leaders who would be able to work in this new environment [1]. Whether stakeholders in education have heard of this term or not, the question is the same. Is it possible to tell with reasonable certainty what the educational environment will be like a year from now? Can anyone predict how many people will be infected with coronavirus in the coming months and how many will die? When will a treatment or 
vaccine for coronavirus be available? Can anyone know when schools will reopen? Will national and international examinations take place as scheduled? We are facing a black-swan event (events nobody believes to be possible until these happen) in a VUCA world. As the Coronavirus continues to spread worldwide, there is a lot of uncertainty around how it will affect students' learning and eventually their academic performance. These circumstances are forcing Education Ministries and schools worldwide to create plans swiftly to maintain connections with students and make learning possible even when no one is in the school building [2]. Current educators did not prepare for such a situation. However, times of VUCA require daring innovation and the skills couplet that enables the continuous realization of the desired future.

In this VUCA era, educators and administrators need to learn new skills promptly, the description is highlighted in Table 1[3]. As from now, teachers and administrators alike need to accept that they have to venture into full-scale remote learning which involves the unpredictable and the uncomfortable. They cannot rapidly change that, so they should turn their priorities to what is within their control. This is not a time for scripted lessons and rigid implementation. This is a time for educators to focus on core learning priorities, to be intentional in how to support students, to continue learning, and to be flexible in their expectations [4]. It is a tremendous disruption to each school's activities and asks a great effort to all stakeholdersalike. In this VUCA scenario, educational administrators and teachers need primarily to:

- stay calm, because students need stability and they are the role models;

- care for their students and make sure everybody feels welcome, understood, appreciated and loved;

- make small decisions swiftly, learn from them, and adapt so that they can survive in the current VUCA situation and are not overwhelmed by the dire circumstances.

\subsection{Imparting communication technologies}

It is imperative to understand the characteristics and affordances of different types of technologies to have a clear idea of their possible usefulness or limitations for remote education. This will also enable us to understand the that or specific features of technology. There are several features of communications technologies, but they are especially important for education[5].

$>$ Give (one way) or (two way) internet media;

$>$ Communicating with bidirectional technologies;

$>$ Single or rich media.

Table 1: VUCA at a glance

\begin{tabular}{|c|l|}
\hline VUCA terms & \multicolumn{1}{|c|}{ Explanation of each term } \\
\hline Volatility & $\begin{array}{l}\text { We live in a world that is becoming more } \\
\text { unstable day after day, where changes } \\
\text { are frequent and more erratic. As events } \\
\text { develop in completely unpredicted ways, } \\
\text { it is becoming tough to determine cause } \\
\text { and effect. Constant learning, access to } \\
\text { new knowledge and technology are the } \\
\text { first way to communicate with the VUCA } \\
\text { environment. }\end{array}$ \\
\hline Uncertainty & $\begin{array}{l}\mid c \\
\text { experiences are not very effective to } \\
\text { forecast events or envisage how they will } \\
\text { unfold. The strategy for development and } \\
\text { growth is becoming very difficult as the } \\
\text { timing and magnitude are irregular. The } \\
\text { facility can improve its development and } \\
\text { can be a real competitive advantage by } \\
\text { promoting mobility, making constructive } \\
\text { efforts, planning for constant change and } \\
\text { learning to adapt. }\end{array}$ \\
\hline Complexity \\
$\begin{array}{l}\text { In our increasingly complex world, } \\
\text { impediments and their implications are } \\
\text { more multi-layered, making it tough to } \\
\text { get an overview of how things are related. } \\
\text { Selecting a single correct path is almost } \\
\text { enigmatic. It is essential for knowledge } \\
\text { workers to start thinking in new ways, } \\
\text { exploring new solutions, and innovate. }\end{array}$ \\
$\begin{array}{l}\text { One size fits all, routines and best } \\
\text { practice are rare. Nothing is black and } \\
\text { white - grey is more common. The } \\
\text { demands on modern organizations are } \\
\text { incongruous. Making decisions requires } \\
\text { audacity, alertness, and a preparedness } \\
\text { to make mistakes. }\end{array}$ \\
\hline
\end{tabular}

\subsection{Give (one way) or (two way) internet media}

Broadcasting is the diffusion of audio or video material to a scattered audience via any electronic mass communications device [6]. The examples of broadcasting and one-way media are television, radio, film, audio or podcast, as end users cannot change the message. They can, however, view it differently or even disregard it. The advantage of broadcast media and technology is that all students receive common instruction and curriculum materials that are typically consistent. Media of public interest such as radio 
and television often ensure the pathways for students not being shut down, particularly from poorer backgrounds, who are not able to access the technology or Internet. Furthermore, radio broadcasters allow the institution to monitor and maintain quality control of the information transmitted [7]. The media and technology for broadcasting including recorded lectures and blogs are more likely for educators with an objectivistic pedagogical approach, since all students receive the same content. The disadvantages are that it does not permit interaction with teachers or other learners, there is no immediate feedback, it is not media-rich and it does not cater for multiple intelligences[8].

The most popular forms of networking or technology are video conferencing, webinars, online chat and media channels, in which all users can communicate with one another. Based on their architecture, websites may vary from where they are located. For example, online quizzes allow students to interact, though they are not able to communicate or change the content. The educational importance of communicative media is that it facilitates contact between educators and students, requires direct input and is typically information-rich, and therefore caters for multiple intelligences. In comparison, various formats (text, graphics, audio, film, animation, simulations) are best suited for students with specific forms of learning and different needs of communicative technology [9]. The mentally synthesis of information obtained through different media originating from a number of channels is also an improved awareness of dynamic processes [10]. In the use of broadcast or communicative media, the position of the instructor is quite different. The role of the teacher in broadcast media is significant because the material is chosen and distributed by the teacher. Nonetheless, while the role of the teacher can still rule the contact environment, like video conferences, learning circumstances are not dominant, with participation from all members of the group. there are no clear statistics. Any member of a learning group contributes, therefore, to a constructivist approach to the creation and distribution of knowledge [11]. The critical decision for an educator is to agree on the optimal balance between the newspapers. The decision will depend on how much the teacher is at ease with technology and what facilities are available in terms of hardware, software, networks, and services.

\subsection{Communicating with bidirectional technologies}

Both those engaged in collaboration will take part in synchronous technologies together, but not always in the same place. Video conferences, webinars, and chat conversations are examples of synchronous technologies [12]. The advantages are that they enable interactions, questioning, and sharing of ideas. For effective synchronous lessons, strategies that can be used include advance mobilization of resources, explicit instructions to learners and clear learning outcomes [13]. Participants canview information or interact at various times using asynchronies technologies. Any media reported is asynchronous. The asynchronous media and technology are books, DVDs, YouTube videos, lecture recordings and available for on-demand viewing as well as on-line conversation for a (Table 2). Learners can sign in or access these technologies at times and at the location of their choosing, providing more versatility and control [14].

Table 2: Synchronous and asynchronous

\begin{tabular}{|c|c|c|}
\hline Synchronous & Asynchronous & The flexibility of \\
\hline $\begin{array}{l}\text { Chat } \\
\text { Instant } \\
\text { Messaging } \\
\text { Video and audio } \\
\text { conference } \\
\text { Live webcasting } \\
\text { Shared } \\
\text { Whiteboard }\end{array}$ & $\begin{array}{l}\text { E-mail } \\
\text { Discussion } \\
\text { forum } \\
\text { Wiki } \\
\text { Blog } \\
\text { Recorded } \\
\text { lectures }\end{array}$ & $\begin{array}{l}\text { Internet } \\
\text { technology } \\
\text { creates } \\
\text { intermediate } \\
\text { areas around the } \\
\text { concepts of } \\
\text { synchronous } \\
\text { and } \\
\text { asynchronous } \\
\text { means of } \\
\text { communication. } \\
\text { Video and audio } \\
\text { sessions will, for } \\
\text { example, be } \\
\text { captured and } \\
\text { made available } \\
\text { to students not } \\
\text { interested in a } \\
\text { live event. }\end{array}$ \\
\hline
\end{tabular}

\subsection{Single or rich media}

Media richness is increased by incorporation more means of communication. Early textual content contained illustrations and sketches as well as rich words. TV or photo combines both audio and static and shifting pictures. Multimedia is the integration of many types of media such as text, graphics, still images, audio, video, animations, simulations and interactive contents in the same information unit. When an assembly of digitally linked contents is created through which the user can navigate, interactive 
multimedia becomes hypermedia [15]. Multimedia applications have evolved to a stage of causing a paradigm shift in information transfer and presentation. Professional and eye-catching videos use the influence of audio coupled with complex graphics very successfully to reach the viewer. However, appropriate planning should be made before filming to ensure that the procedures are explained accurately and clearly. The length of the video is also significant. A shorter 10 minutevideo for example is easier to handle than a 50 minute continuous film. Just how rich will the media be to know efficiently? If too much knowledge is provided to students at or too quickly to assimilate at a point, cognitive overload can occur [16]. In the planning of rich media, attention must be given to Vygotsky's Proximal Growth Zone (the contrast between what a learner can do without help and what can be achieved with support). The rich media have benefits over the traditional contact medium from an educational standpoint, as the rich media helps the instructor to communicate with multiple intelligences. Numerous science practical, mathematical reasoning or physical exercises can be recorded in a multimedia layout and made available for viewing at any time. Processes too complex to show in class can often be demonstrated through animation, projections, video recordings or virtual reality.

\subsection{Implementation of remote learning}

The place of learning in a VUCA environment moves from classroom to a 24/7 network-a remote learning area. However, educators and administrators for whom remote learning seems daunting need support and guidance to use the resources available optimally [17]. Every educator needs a framework to help determine how resources and digital tools available can be used to have the desired effect. Therefore, to implement remote learning successfully and in line with core educational principles and objectives, each educator needs to assess his specific situation:

- What do I want to achieve, and what is my capability to achieve it?

- What is considered valid forms of learning regardless of physical setting?

- What are the core learning priorities for my class? For my students?

- When it comes to interactions with content and interactions with students, what forms are comfortable for me?
- What forms of interactions would serve the core learning priorities and enable effective learning to take place?

- Will this differ from student to student, and am I prepared to facilitate that diversity in instruction?

The easiest activities to set up remote learning activities are

\section{Content production and collaborative writing}

There are various free or inexpensive approaches for electronic word processing. Examples like Google Classroom, Zoho. Google Docs help interactions such as the editing and commenting on a shared digital document. Assigning collaborative tasks (posters, projects, group discussions, etc.) by pairing or grouping students can promote motivation and increased participation.

\section{$>$ Short screencasts}

Through creating short videos to illustrate and incorporate core concepts into Google Classroom, students will have a close interacting interaction with their teachers through easy applications like 'Flipgrid.' Students sign themselves and then upload these images, e.g. reading poetry aloud.

\section{Multimedia presentations}

For graphical presentations PowerPoint may be used, but more detailed infographics and immersive presentations are possible. Examples are Beautiful.ai, Piktochart.com and Slides.com.

$>$ Quizzes, polls, and surveys

This is easy to access online. For instance: Easypoll, SurveyMonkey, Typeform, etc.

$>$ Games and simulations

There are several options for online educational play. Examples: digital phet models, national geographic babies, the future of the earth.

\section{Video chatting and conferencing}

There are various free or incorporated programs available. Examples: FaceTime, Microsoft Teams, Zoom. Learners should be encouraged to maintain a journal to note down their difficulties and queries on assignments, which in turn should help teachers to have productive lessons/questions \& answers sessions. Public media are still being incorporated into formal education, and their primary educational interest has been in non-formal education, such as the creation of 
online research groups. However, they have much greater potential for learning, Today, students in our educational institutions are from Generation $Z$, a community that has grown up in a genuinely globalized and technical environment. The generation, often characterized by the words FOBA (Fear of being alone) and Fomo (Fear of missing people), usually communicates its desires through the use of apps such as Facebook, Instant Messenger, Snapchat and WhatsApp for messaging, instant contact and feedback.

\section{$>$ Online learning management venue}

Learning management systems can be used to store lecture notes in the form of slides or PDFs, links to online readings can be made accessible, or online discussion boards can be created. Online instruction can also be paired with person-to-person training. If a lesson is taken up, students will look at it on their own time, and then the on-line classroom time, can contribute to a flapped classroom paradigm is used for more engaging sessions. LMSs offer an electronic classroom platform where content can be installed and arranged, and offer "spaces" for learning targets, student events, homework questions and discussion forums. Learning management systems (LMS) are used for the establishment of online courses. An LMS shops unit and course schedules, which also contains events including chat boards, quizzes, which e-portfolios. Open source learning management solutions exist as well, but an IT professional needs to set up and retain them.

$>$ Ensure that online teaching does not disadvantage students

Bodacious online education is not the same thing as face-to-face classroom instruction. It calls for various online practices. But if students do not have other personal and electronic learning opportunities, students are disadvantaged. Different learning activities can ensue using smartphones and tablets.

\section{$>$ Internet access}

Poor bandwidth can make many synchronous activities very difficult, thus asynchronous activities should be favored. For students who do not have access to technology or internet connectivity, especially those from disadvantaged families, mobile check-ins and public interest media like radio and television can help sustain education.

\section{$>$ Shorter class times with fewer students}

Moving teaching schedules to shortened class periods and more sessions, but fewer students at a time are more effective in online learning scenarios. When class hours are paired with group events, students are more likely to sign in and complete assignments or discussions.

\section{$>$ Effective feedback}

Ample feedback and communication between instructor and learner are essential. Students may also potentially receive useful input from online quizzes, as well as direct suggestions or conversations from peers and educators.

\section{$>$ Opportunities for independent learning}

Students know informally all the time in any case. Designing learning exercises and conversations that reflect students' perspectives while keeping them involved and providing teachers with useful input about how learners feel. It also provides opportunities for different learning experiences which does not exist while students are in a classroom together physically.

\section{CONCLUSION}

The human understanding and knowledge scope are expanding very quickly nowadays, generating new forms of thinking. Technologies are becoming more communicative and media rich, thus offering educators and students effective tools to attain desired learning outcomes. In a world where knowledge is only a few 'clicks' away, the potential exists for educational institutions to enable continuous learning and evaluation in times of VUCA. A time of crisis is also an opportunity for educational institutions to think about the future, adjust to possible threats, and build their capacity. Knowledge workers need to understand that a VUCA environment asks for audacity, agility, alertness, exploration of new solutions, innovation, and preparedness to make mistakes. What, when and what to know transforms the idea of playlists as a set of activities to be tackled by students at their own time to personalize interactions. This will greatly impact higher education, as talents need to be consistently built in life to address new obstacles and possibilities in the workforce and the world. Finally, if educators commit to maintaining the continued access of their students to high-quality education even in difficult periods, 
their esteem for them will increase, which has lately declined.

\section{REFERENCES}

[1] J. Bartscht, "Why systems must explore the unknown to survive in VUCA environments," Kybernetes, vol. 44, no. 2, pp. 253-270, Feb. 2015, doi: 10.1108/K-09-2014-0189.

[2] S. Ashraf, A. Raza, Z. Aslam, H. Naeem, and T. Ahmed, "Underwater Resurrection Routing Synergy using Astucious Energy Pods," J. Robot. Control JRC, vol. 1, no. 5, 2020, doi: 10.18196/jrc. 1535 .

[3] B. Means, Y. Toyama, R. Murphy, M. Bakia, and K. Jones, Evaluation of Evidence-Based Practices in Online Learning: A Meta-Analysis and Review of Online Learning Studies. US Department of Education, 2009.

[4] S. Ashraf, M. Gao, Z. Mingchen, T. Ahmed, A. Raza, and H. Naeem, "USPF: Underwater Shrewd Packet Flooding Mechanism through Surrogate Holding Time," Wirel. Commun. Mob. Comput., vol. 2020, pp. 1-12, Mar. 2020, doi: $10.1155 / 2020 / 9625974$.

[5] Y. Digumarthi, T. Ravi, and G. S. Jegan, "BIDIRECTIONAL COMMUNICATION IN LI-FI TECHNOLOGY,"2016. https://www.semanticscholar.org/paper/BIDIRECTIONA L-COMMUNICATION-IN-LI-FI-TECHNOLOGY-DigumarthiRavi/0214762204bf792b772ae32abd1e4b2f79d2d10a (accessed May 08, 2020).

[6] S. Ashraf, M. Gao, Z. Chen, S. Kamran, and Z. Raza, "Efficient Node Monitoring Mechanism in WSN using Contikimac Protocol," Int. J. Adv. Comput. Sci. Appl., vol. 8, no. 11 , 2017, doi: 10.14569/IJACSA.2017.081152.

[7] B. Herold, "The Disparities in Remote Learning Under Coronavirus (in Charts) - Education Week," Education Week, Apr. 29, 2020

[8] "LT Germany | OEB." https://oeb.global/learning-technologies-germany (accessed May 08, 2020).

[9] S. Ashraf et al., "Underwater Routing Protocols Analysis of Intrepid Link Selection Mechanism, Challenges and Strategies," Int. J. Sci. Res. Comput. Sci. Eng., vol. 8, no. 2, pp. 1-9, Apr. 2020, doi: 10.26438/ijsrcse/v8i2.19

[10] "Best Practices for Effective Video Conferencing | University https://uit.stanford.edu/videoconferencing/best-practice s (accessed May 08, 2020).

[11] S. Ashraf, T. Ahmed, A. Raza, and H. Naeem, "Design of Shrewd Underwater Routing Synergy Using Porous Energy Shells," Smart Cities, vol. 3, no. 1, pp. 74-92, Feb. 2020, doi: 10.3390/smartcities3010005.

[12] S. Ashraf, T. Ahmed, S. Saleem, and Z. Aslam, "Diverging Mysterious in Green Supply Chain Management," Orient. J. Comput. Sci. Technology, vol. 12, no. 2, pp. 34-38.

[13] S. Ashraf, S. Saleem, and T. Ahmed, "Sagacious Communication Link Selection Mechanism for Underwater Wireless Sensors Network," Int. J. Wirel. Microw. Technol., vol. 10, no. 2, pp. 12-25.

[14] "Managing in the Next Society - 1st Edition - Peter Drucker - $\quad$ Routledg." https://www.routledge.com/Managing-in-the-Next-Societ y/Drucker/p/book/9780750685054 (accessed May 08, 2020).

[15] "New Ways of Using Multimedia in Classroom EdTechReview ${ }^{\mathrm{TM}}$ (ETR)."

https://edtechreview.in/trends-insights/insights/746-ne w-ways-of-using-multimedia-in-classroom (accessed May 08, 2020).

[16] "What a difference a word makes: Understanding threats to performance in a VUCA world | harishdarapu -Academia.edu."

https://www.academia.edu/34705018/What_a_difference _a_word_makes_Understanding_threats_to_performance_i n_a_VUCA_world (accessed May 08, 2020)

[17] "What Administrators Are Asking About Remote Learning | EdTech Magazine."

https://edtechmagazine.com/k12/article/2020/04/whatadministrators-are-asking-about-remote-learning (accessed May 22, 2020). 